\author{
Радоје В. Шошкић \\ Универзитет у Приштини са привременим седиштем у Косовској Митровици \\ Филозофски факултет, Косовска Митровица \\ e-mail: soskicradoje@gmail.com
}

\title{
МОТИВ ХРИСТОВОГ ДРУГОГ ДОЛАСКА У ДРАМИ БЛУЗ ЗА МЕСИЈУ АРТУРА МИЛЕРА*
}

Апстракт: Након бројних комада у којима је оцртавао развој савременог америчког друштва без искорака из конвенчија реалистичног приказивања, амерички драмски писаи Артур Милер је пред крај свог живота крајње критички проијењивао америчку друштвену стварност кроз оптику хришћанске етике, те у том свијетлу ваља разумјети његово инкорпорирање мотива о Христовом другом доласку у драми Блуз за Месију (Resurrection Blues, 2002), што је и тема овог рада. У хиперреалности XXI стољећа, Исус Христ (оваплоћен кроз лик револуционара Ралфа) у свом другом доласку доживљава да опет буде разапет, а од ијелокупног догађаја, прилагођеног савременој ери масовних медија, селебрити културе, рекламе и сензачије бива начињен спектакуларни телевизијски пренос. Теоријски оквир за наша разматрања представљају идеје Николаја Берђајева за кога преобраћање човјекове личности, која је етичка и духовна категорија, у ствар, објект и безличну стихију значи смрт, док у сукобљавағу моћи и надличних, виших вриједности, тријумфују оне ниже. Такође, наша промишьььа се темеље и на концептима Жана Бодријара, Беле Хамваша, Криса Хециса и Зигмунта Баумана који тврде да је савремени флуидни живот заправо потрочачки живот који свијету и свим юеговим живим и неживим фрагментима додјељује улогу објекта потрошие.

Кључне ријечи: Исус Христ, Блуз за Месију, распеће, селебрити култура, потрочачки живот, стварност, опсјена.

У једном чланку објављеном 1992. године у „Њујорк тајмсу“ Артур Милер, у маниру Џонатана Свифта, одлучно је саопштио да је дошло вријеме да се размотри могућност приватизовања погубљења тако што би их ваљало учинити јавним. Детаљну слику макабричног јавног погубљења на електричној столици на Шеа Стадиону (Shea Stadium), аутор употпуњује призором исплаћивања хонорара свима који учествују у том језивом подухвату. Милер сатирично препоручује Америци да ће трансформисањем погубљења у забаву доступну цјелокупној јавности смрт криминалаца претворити у огољени спектакл налик свечаности каква се виђа током полувремена Супербоула (енг. Super Bowl). Једино тада, додаје Милер, „почећемо да постављамо питање о томе зашто

* Овај рад је дио истраживања које се изводе на пројекту Превод у систему компаративног изучавања српске и стране књижевности и културе (бр. ОН178019), који финансира Министарство за науку и технолошки развој Републике Србије. 


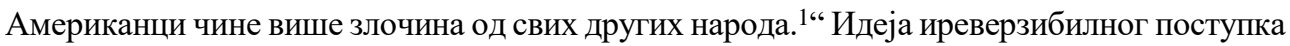
као подстицаја за катарзу а потом и друштвену промјену чини основу овог Милеровог „скромног“ предлога ${ }^{2}$ и истовремено темељ његовог комада Блуз за Месију, објављеног 2002. године, који тематизује комерцијализацију погубљења Ралфа (у драми оваплоћење Исуса Христа), који је у врлом новом миленијуму претворен у селебрити (енг. celebrity), и коме Феликс и остали ликови приписују вриједност само зато што има способност да им донесе профит. Његова смрт распећем биће трансформисана у мегаспектакл притом постајући предмет безочне комерцијализације гдје приступ имају сви - и посматрачи, гледаоци, блазирани рекламождери и режисери као креатори слике прилагођене жељама конзумената. Претварањем смртне казне у шоу, прекидајући њену драматичност рекламама о љековима за атлетско стопало, жгаравицу, констипацију и свраб ануса, Милер очито вјерује да би се Америка на концу можда могла одрећи праксе погубљења, али не из осјећања моралног гнушања већ из досаде.

Радња Блуза за Месију јесте смјештена у наоко безначајној и удаљеној држави, али је зато глобална партиципација у спектаклу загарантована. Сотона је Христа искушавао нудећи му неограничену власт над свијетом. ${ }^{3}$ У Милеровој драми таква понуда и искушење бивају обновљени и прилагођени напредном свијету симулације и нарцисоидности који тражи ужитке. ${ }^{4}$

У неименованој колонизованој удаљеној земљи, а како комад одмиче све више постаје јасно да је ријеч о некој земљи из Јужне или Средње Америке чији становници још увијек памте шпанске конкистадоре и према којој су САД одувијек имале империјалистичке претензије, 2 процента баснословно моћних и богатих контролише 96 процената земље. Грађански рат који је отпочео прије готово четири деценије и даље траје. Револуција је пропала будући да су се њени некадашњи вође нагодили са колонизаторима обезбиједивши себи на тај начин успјешан и лагодан живот. Неправда, насиље и сиромаштво харају, доминантно осјећање је очај, очеви од својих осмогодишњих кћерки праве проститутке, дјеца убијају старе људе због обуће, у најпрестижнијем и најраскошнијем шопинг дистрикту пјешаци уопште не обраћају пажњу на мртве бебе које леже у сливницима, ваздух је толико загађен да је постао кисјео, усљед чега се љушти чак и боја са платна слика насликаних у осамнаестом стољећу, застарјели подземни водоводни и канализациони систем подрио је темеље вила у једној имућној четврти до те мјере да чак и тежина клавира који се налазе у њима сваког тренутка може допринијети њиховом урушавању. Цркве су претворене у простор за игре на срећу, дјеца пате од болести јетре узрокованих паразитима којима је заражена пијаћа вода и који доводе до настанка паразитске болести - шистозомијазе, чак и они

1 Arthur Miller, “Get It Right. Privatize Executions.” May 8, 1992, доступно преко: http://www.nytimes. com/books/00/11/12/specials/miller-executions.html Превео са енглеског аутор рада.

2 Алузија на сатирични есеј Један скроман предлог (A Modest Proposal, 1729) Џонатана Свифта.

3 Библијска приповијест о Сотониним искушењима Исуса Христа осуђује похлепу за имањем ствари и жудњу за моћи те другим манифестацијама модуса имања. На први покушај искушења претварања камења у хљеб, што симболички изражава тежњу за материјалним добрима - Христ одговара: „Не живи човјек о самоме хљебу, но о свакој ријечи која излази из уста Божјих“ (Матеј, 4:4; Лука, 4:4). Сотона тада искушава Христа обећавајући му потпуну власт над природом (измјеном закона гравитације) и на крају неограничену моћ власти над свим краљевствима на Земљи, што Христ одлучно одбија (Матеј, 4:5-12).

4 Све неодољиво подсјећа на Хакслијев врли нови свијет из истоименог романа, гдје се појединац рађа и живи у великим владиним зградама гдје га одгајају као роб(от)а. Друштво је подијељено на неколико касти од којих је само једна привилегована и контролише све живо и неживо. Религија је укинута и замјењује је култ задовољства и хедонизам (конзумеризам). 
најбогатији и најмоћнији лете у Мајами ради одговарајуће здравствене његе. У хиперреалности XXI стољећа, Божији Син (у драми Ралф) се поново враћа на земљу да искупи човјечанство од његових искварених вриједности. Властодршцима (поменуте подјармљене земље) поново пријети иста она опасност када је Он први пут боравио на земљи. Генерал Феликс Барио, вођа војне хунте која влада земљом, хапси наводног револуционара Ралфа који се појављује како би проповиједао о правди и љубави, за кога сељаци вјерују да је истински Месија. Немајући другог оружја сем јеванђеља љубави и филозофије пацифизма ${ }^{5}$, Ралф представља отјеловљење Исуса Христа, и једина револуција на коју он може подстаћи потлачене сељаке јесте револуција наде и вјере у циљу остварења цјеловитог бивања. Узнемирен усљед могућности да би могла избити револуција, јер земља коју он контролише и експлоатише заправо припада обесправљеном и осиромашеном народу, Феликс одлучује да ликвидира Ралфа разапињањем на крст. Његово распеће, прилагођено савременом тренутку - ери масовних медија, рекламе, сензације, гдје Христ не само да постаје предмет разапињања на крст већ се од њега тражи да чак и пристане на предности живота (конформизам) у друштву унутар којег нико нужно не мора бити губитник уколико само интернализује логику монетарне економије, донијеће Феликсу баснословну своту новца јер је он уговорио телевизијски пренос распећа са највећом рекламном агенцијом за фармацеутске компаније у САД-у. Вриједност уговореног посла износи безмало 75 милиона долара; ријеч је о снимању двадесетчетворочасовног ријалити програма, у којем би Ралфово (Христово) распеће преносила америчка телевизијска мрежа уз неопходне рекламне паузе, током којих би се промовисали различити производи за његу тијела, почев од дезодоранса, препарата против опадања косе, суве и осјетљиве коже, па све до таблета против импотенције. Чак и сељаци који према Ралфу гаје страхопоштовање желе да профитирају од тог мегаспектакла, очекујући туристички бум и инвестиције у изградњу инфраструктуре.

Слика ове јалове и беживотне земље представља имагинарну верзију САД-а, истовремено драматизујући посљедице ентропије 6 - неизбјежно трошење физичког свијета и културних система, и њену моћ да „поништи поредак и покрене ка смрти.“7 У својој студији о Милеру Кристофер Бигзби наглашава да Америка, као и ова измишљена земља, такође представља пост-револуционарну културу, чија су главна обиљежја „дрога и звук пуцња из ватреног оружја у ноћи.“ И Америка је, такође, једно друштво крајности, унутар којег је „религија склопила профитабилан пакт са Мамоном.“8 У земљи из комада Блуз за Месију, као што смо већ нагласили, 2 одсто популације држи 96 процената богатства земље у својим рукама. У Америци, 2000. године, 1 проценат људи држао је у својим рукама 46 процената богатства, док је 10 процената популације контролисало 73 одсто богатства. Независно од тога да ли је ова латиноамеричка земља верзија САД-а или не, чињеница је да је Америка референтна тачка.

Свијет осликан у драми налази се у знаку напетости месијанизма и диктатуре. Свјесни импликација појаве Ралфа, то јест Христовог Другог доласка, Феликс, хибрид Шекспировог Ричарда III, Хитлера, Аугуста Пиночеа и Достојевсковог Великог

5 „Никог није наоружао“, каже режисерка Емили Шапиро.

6 Ричард Лехан (Richard Lehan) у својој студији Град у књижевности: интелектуална и културна историја (The City in Literature: An Intellectual and Cultural History, 1998) објашњава ентропију ријечима: „Доведен до коначног исхода, други закон термодинамике казује да ће свемир губити топлоту у складу са законом ентропије све док сва материја и сва енергија не буду сведене на коначно стање униформности.“ Види: Lehan 1998, 269. Превео са енглеског аутор рада.

7 Lehan 1998, 270. Превео са енглеског аутор рада.

8 Bigsby 2008, 425. Превео са енглеског аутор рада. 
инквизитора, из чијих ријечи громко одзвањају наполеонске тежње, херојске амбиције и војна слава - обиљежја САД-а, и Хенри, његов рођак, филозоф из досаде, дискутују о ефектима разапињања Ралфа на крст:

ХЕНРИ: Када смо путовали ка Санта Феличеу - Хилда и ја - смо били задивљени ... како бих рекао? [...] призором некаквог духовног феномена тамо горе. Заиста је било невјероватно. Гдје год смо пошли сељаци су држали у рукама слике овог младог човјека кога они ...

ФЕЛИКС: С њим је свршено. Ухапсили смо га, Хенри, готов је, готова је то ствар. ХЕНРИ: Они држе упаљене свијеће испред његове слике, знаш ... као да је светац. ФЕЛИКС: Злочинци овог свеца су пуцали на три полицијске станице и усмртили два полицајца и ранили још петорицу у посљедњих пет мјесеци.

ХЕНРИ: Они кажу да он лично није имао никакве везе са тим чином насиља.

ФЕЛИКС: Тај човјек је револуционар и сноси одговорност! [...]

ХЕНРИ: Кружи једна гласина - у коју тешко могу повјеровати - да намјераваш разапети овог типа?

ФЕЛИКС: Не могу коментарисати то.

ХЕНРИ: Молим?

ФЕЛИКС: Немам коментар, Хенри, крај приче.

ХЕНРИ: А шта ако то доведе до крвопролића?

ФЕЛИКС: Мислим да неће.

ХЕНРИ: Феликсе, уопште не схваташ поенту. Они (народ) заиста вјерују да је он Месија, Син Божији.

ФЕЛИКС: Син Божији је човјек чије је име Ралф?!?

ХЕНРИ: Али разапињање! Зар не схваташ? - то ће бити доказ тога да су они били у праву! Они су прост народ, то би их могло подстаћи на устанак!

ФЕЛИКС: Само убијање више не пали! Људе убијају на телевизији на сваких десет минута; бенг-бенг, и људи падају к’о крушке, то је бесмислено. Али само ли разапнеш пар оваквих проклетника на крст, вјеруј ми да ће ово бити најмирнија земља на континенту и спремна за развој! Распеће увијек смирује ситуацију. Заиста, у чуду сам - један кретен се латио проповиједања о проклетој револуцији, док ти ...

ХЕНРИ: Разговарај с људима! Рећи ће ти да он проповиједа о правди.

ФЕЛИКС: Ма дај, Хенри. 2 одсто наших људи - укључујући и тебе - посједује 96 посто земље. Правда коју они захтијевају је твоја земља; и да ли си спреман да им је предаш? ${ }^{9}$

Сваки траг независне духовности (Исус Христ) треба уништити као заразно легло да би се отворио пут за настанак и развој свемоћног приземног човјека (Феликс) кога уобличава технократска идеологија.

На земљишту пресахлих вриједности нема пуно изгледа за раст хероизма. У очима чистокрвних Американаца (Хенрија и Феликса) аскета (Христ) није ништа друго него дангуба и друштвени паразит, а херој у античком смислу само је нека врста опасног лудака кога треба одстранити, док се фанатични пуритански моралиста обавија блиставим ореолом. Флуидно модерно потрошачко друштво не оставља мјеста ни за мученике ни за хероје. Такво друштво, вели Зигмунт Бауман, „поткопава, оспорава и бори се против двеју вредности [...] против жртвовања садашњих задовољстава у име далеких

9 Miller 2009 138-139. Превео са енглеског аутор рада. 
циљева, и тиме против прихватања дуготрајне патње у име спасења у животу након смрти [...] Друго, оно доводи у питање вредност жртвовања личних задовољстава у име благостања или у име 'циља' (оно заправо оспорава постојање група 'већих од збира њених делова' и циљева који су важнији од личног задовољства).“10

Хенри признаје да му недостаје храбрости и вјере те покушава да одврати Феликса од идеје распећа видећи у томе крах њихове владавине, скори крај свијета. Феликс на то одговара:

ФЕЛИКС: [...] Могу ти рећи да ће тек након овог распећа наша земља коначно почети да живи. [...] Наш дигнитет јесте модернизација. ${ }^{11}$

Под изговором технолошког прогреса, агенти комплекса моћ-новац, због финансијског профита и због властите заштите, сматрају својом обавезом избрисати сваки траг једне хуманије прошлости.

Хенри, кога изједа хронични осјећај кривице због безобзирног начина пословања његове фармацеутске компаније и коме недостаје Феликсова вјештина (доведена до перфекције) пренебрегавања чињенице да многи сељаци пале свијеће као вид одавања поште Ралфу за кога интуитивно вјерују да је Месија, опомиње Феликса да ће ако свој план спроведе у дјело завршити на страницама историје бешчашћа и зликоваца гдје једно од главних мјеста заузима Понтије Пилат:

ХЕНРИ: Не схваташ, Феликсе! Људи на овом свијету очајнички траже неког ко саосјећа с њиховим патњама и коме је стало до њих! Тај човјек представља наду! ФЕЛИКС: Он представља наду јер ће нам донијети 75 милиона долара!

$$
\text { [...] }
$$

ХЕНРИ: Феликсе, ако продаш овог човјека, придружићеш се двојици најодвратнијих чудовишта у историји.

ФЕЛИКС: Којој то двојици?

ХЕНРИ: Понтију Пилату и Јуди, за име Бога! Такве срамоте тешко је отрести се. ФЕЛИКС: Али Исус Христос није био варалица, али овај тип јесте.

ХЕНРИ: То не знамо.

ФЕЛИКС: О чему ти ког ђавола говориш, тај кучкин син није чак ни Јеврејин! Побогу, Хенри, с толиким новцем моћи ћу да набавим полицајцима пристојну обућу и сваком од њих купим по један пончо. И праву канализацију [...] са водоводним ичјевима! - тако да виша класа људи неће убудуће морати да гради куће на врховима брда [...] могли бисмо имати и нашу сопствену авионску линију и слати наше проститутке код зубара $\left[\ldots . .{ }^{12}\right.$

Моћни тиранин говори у име општег добра али вазда иде за приватним интересом. Диктат новца и профита очито је попримио алармантне размјере. Феликс је способан мислити једино у новчаним размјерама, новац је за њега постао облик активног бића уопште. Обезличавајућа сила новца неповратно празни саму срж ствари, њихову индивидуалност и специфичну вриједност: „Он (новац, прим. Р. Ш.) не цени више ствари према њиховим међусобним односима, већ у односу на себе самог. [...] Новац је сада

10 Bauman 2009: 60-61.

11 Miller 2009, 144-145. Превео са енглеског аутор рада.

12 Ibid., 142. Превео са енглеског аутор рада. 
постао сила, и то чисто духовна сила коју метал само репрезентује [...] Постоји „мишљење у новцу“, као што постоји и математичко мишљење, јуристичко мишљење.“13

У једном интервјуу из 1984. године који је Милер дао за Royal National Theatre, Кристофер Бигзби га је упитао: „Које је то морално питање данас које заслужује драму написану од стране Артура Милера?“, на шта је Милер одговорио: „Оно што ме све више и више фасцинира јесте проблем стварности, питање шта је то стварност, и да ли је уопште има, и како трагати за њом. То је, на крају крајева, морално питање, али не бих сада залазио у теологију.“14 Током цијелог комада Блуз за Месију, иста проблематика притиска свијест Хенрија Шулца, филозофа и фармацеутског магната. Он такође преферира филозофски вокабулар у односу на теолошки. Будући да идеју разапињања невиног човјека Хенри сматра гнусном, он покушава да убиједи Феликса да одустане од тог плана јер ће он „довести до крвопролића.“"15 Оног тренутка када увиди да његов апел не успијева уродити плодом, Хенри преобликује своју аргументацију не би ли наговорио извршног продуцента Скипа Чизбороа, који у преносу распећа види јединствену прилику да се домогне Холивуда, да ће телевизијски пренос распећа само нашкодити интересима медија:

ХЕНРИ: Господине Чизборо, цијелог живота сам покушавао да се ослободим досаде реалности. Наравно, много сам повриједио неке мени врло драге особе као што то и чине они који бјеже од стварности. Осим што ми је свега доста, сада сам убијеђен да - већина људских дјелатности - спорт, опера, телевизија, филмови, облачење одјеће, свлачење одјеће - или једноставно одлазак у шетњу - имају превасходно за циљ да нас уведу у свијет имагинације. Имагинација је огромна дворана гдје се смрт, на примјер, претвара у умјетничку слику, а крик бола постаје пјесма. Дворана имагинације представља уистину оно мјесто гдје ми обично пребивамо; и све је то у реду изузев једне ствари - да би човјек ушао у ту дворану он мора оставити своју истинску тугу на њеним вратима и умјесто ње окружити се сликама и ријечима и музиком које симулирају патњу али су заправо испражњене од ње - нико никада није изгубио ногу читајући о некој бици, или умро чувши најтужнију пјесму. [...] Зато овог човјека морамо уловити и разапети; јер - он још увијек уистину све осјећа. Замислите само, господине Чизборо, када би се такво поштовање према животу проширило! Власти би доживјеле слом, војске распустиле, бракови пропали! На сваком кораку наша беживотна и сурова безобзирност би зурила у нас док се не бисмо згрчили од срама! Не! - боље је да га ухватимо и усмртимо и тако будемо мирне савјести. ${ }^{16}$

Није се обистинило предсказање из романа 1984. Џорџа Орвела, који је страховао од могућности да ће се у будућности забрањивати књиге, да ће човјечанство бити савладано споља наметнутом силом и притисцима. Догодило се нешто много горе и далеко изопаченије, што је наслутио Хаксли; књиге још ријетко ко жели да чита, пошто је зацарила култура нарцисоидности, а с њом и селебрити култура сведена на демонстрацију испразности, индустрију јевтине забаве и потрошачку мегаломанију.

13 Шпенглер 2010, 440.

14 Види: Arthur Miller, interview by Christopher Bigsby, "3 July 1984, Lyttelton Theatre," Platform Papers No. 7: Arthur Miller (London: Royal National Theatre, 1995), стр. 11. Превео са енглеског аутор рада.

15 Miller 2009, 139. Превео са енглеског аутор рада.

16 Ibid., 178-179. Превео са енглеског аутор рада. 
Ликови у Блузу за Месију (Феликс, Хенри, Скип, Емили) оваплоћење су интелектуално-политичко-психолошких проблема савременог америчког друштва. Они симболизују крајњи облик духовног вртлога и моралне тромости који су покренути бјекством од слободе као позива који им је Бог упутио, губитком додира с другим људским бићима и са природним поретком ствари. Скип Чизборо, извршни продуцент, има задужење да уговори посао и прода производ; режисерка Емили Шапиро долази на мјесто догађаја без претходног знања о самом пројекту распећа и томе шта је њен задатак. Скип је безусловни приврженик система који је на власти, јер само тако може да се докопа користи, чинећи све што је у његовој моћи да снимање успије и отпочне на вријеме, све у оквиру предвиђеног буџета. Његов труд иде дотле да чак и пријети Емили да ће јој уништити професионалну каријеру бројним тужбама будући она одбија, више усљед физичког, а не моралног гнушања, да учествује у снимању током којег ће Ралф бити убијен:

ЕМИЛИ: Ечисон ми је рекао да дођем овдје и тачка! Није изговорио ријеч 'умријети'. Нико не умире у реклами! Да ли сте сви ви сишли с ума?'17

Скип у том моменту прибјегава једној врсти здраворазумске декулпабилизације када каже:

СКИП: Ми ћемо то само да снимамо, нећемо да починимо то убиство, побогу! ${ }^{18}$

Присталица медијске псеудологије категорично тврди и да ће снимање распећа довести до тога да сви на свијету прихвате смртну казну као нешто нормално.

СКИП: Да сам моралиста чак бих ти и рекао да ти је дужност да ово снимаш! Заправо, ово би могло да оконча осуде смртне казне широм свијета $[\ldots]^{19}$

Распеће ће бити снимано као што се снима документарни филм. Истовремено, Скип увијек има на уму осјетљиви сензибилитет муштерија и чињеницу да они плаћају ТВ претплату. Сходно томе, Скип истиче љепоту планина као савршену позадину за снимање, као пријатан оквир за распеће. Он се нада да ће захваљујући комерцијалној телевизији сви бити у прилици да гледају распеће из удобности својих домова, откривајући у томе (распећу) симболизам искупљења, а да при том уопште и не осјете забринутост због тортуре и егзекуције једног бића. Хенри би могао да заради големи новац од продаје љекова, новац који ће највјероватније утрошити не на побољшање услова живота сиромашних већ на куповину још једног у низу поклона (клавир) за своју жену. Чак се и ти исти сиромаси који пребивају у планинама надају да ће њихова имања бити одабрана као локација за спектакуларно распеће, све зарад изградње можда чак и коцкарнице и забавног парка. У потпуности индиферентна за људску патњу, публика у театрима и испред телевизијских екрана, апатична и безлична маса посматрача, усавршава свој воајерски менталитет. Скип изнова и изнова понавља да његов задатак није да рекреира Христово распеће, позивајући се на традицију репрезентативне умјетности. Ралф, када буде разапет на крст, мора остати трансценденталан и без иједног знака патње, као што и задивљујући пејзаж, који Скип и Емили уподобљују ради продаје

17 Ibid., 150. Превео са енглеског аутор рада.

$18 \mathrm{Ibid}$. Превео са енглеског аутор рада.

19 Ibid., 151. Превео са енглеског аутор рада. 
спортских рекреативних возила, мора бити у стању дјевичанске љепоте и без икаквих друмова.

Емили је цијели свој живот посветила лажи рекламирања и снимању бескрајних, понајвише посве измишљених, личних драма које су постале базични састојак ексклузивних вијести. Укратко, њена способност је да стварност претвори у умијеће сцене, да стварност саопштава дириговано.

СКИП: Али твоја генијалност је у томе да све што снимаш претвориш у реалност, драга моја -

ЕМИЛИ: Моја генијалност је у томе да учиним да све изгледа лагодно лажно, Скипе. Ниједна агенција не жели стварно. Желите лажно распеће? - зовите мене. ${ }^{20}$

У другој сцени драме пародија добија на замаху када Скип и Емили почну дебатовати о томе да ли би требало наводном Сину Божијем дати љекове против болова док га буду разапињали, а да при том не изгледа пијано и тако увриједи религиозну и смјерну чељад из Канзаса. Скип предлаже аспирин и „тиленол ако је алергичан“, а одбија идеју да би га требало носити до крста будући да би то било доживљено као акт бласфемије у САД-у. Емили, показујући саосјећајност и покушавајући да помогне изнуреном Ралфу, тражи од аморалног Скипа да доведе љекара. Скип, пак, одлучно одбија образлажући свој став да ни љекарска помоћ не долази у обзир јер је то патворење историјских података о распећу.

СКИП: Жао ми је, али не можемо прекрајати историју! [...] Штавише, ја не желим да намећем америчку етику једном достојанственом страном народу. Овдје је обичај да се зликовци разапињу, и тачка. ${ }^{21}$

У Скиповом држању несумњиво препознајемо умртвљујући дух бирократије који је продро у сва подручја живота. Иако код Скипа има елемената садизма, то јест задовољства због владања над другим људским бићем, та садистичка црта тек је секундарна у односу према примарним елементима типа бирократе као што је Скип: непостојање људских реакција и обожавање правила. За њега не постоје људска бића као предмети емпатије и саосјећања.

Умјетност (у случају Емили Шапиро филмска умјетност) у пропаганди постаје слуга, и то служи користи. Стварно је надвладано симулираним и стварност људског живота је изгубљена, односно као што сматра Бодријар - телевизијско, филмско приказивање одређених догађаја суштински узрокује урушавање њихове појавности доводећи до „имплозије смисла.“22 Бодријарова генијална запажања допуњује Хамвашева идеја да је прва лаж - корист учинила да нестане осјећање за вриједности и отвореност према лијепом и узвишеном, као и књижевност, умјетност која критикује живот: „да би неко умео да направи разлику између илузорне и фактичне стварности, потребна је критика; да би неко умео да направи разлику између неистине и истине, за то је потребно осећање за вредности; да би неко начинио разлику између манифестне и латентне

20 Ibid., 152. Превео са енглеског аутор рада.

21 Ibid., 156. Превео са енглеског аутор рада.

22 Види: Baudrillard, Jean. (1994): Simulacra and Simulation. Ann Arbor: The University of Michigan Press. 
историје, за то је потребан геније. “23 Нестала је критика живота, а геније је непрестано под цензуром и налази се у негативној ситуацији. Модерна држава је, каже Хамваш, приморана да развија дезинформативну дјелатност високог степена ради прикривања своје политичке неспособности. Дезинформативна дјелатност је постала толико систематична да је јавност преплављена прештимованим информацијама. Све у циљу да овлада човјеком здраве памети и претвори га у абнормалног:

Да би деморализовала човека није довољно да дезинформише јавно мњење у новинама и на радију и другде закључно са метеоролошким извештајем. Свет треба потпуно преобразити. То се и данас догађа. Систематску дезинформацију треба већ започети у основној школи. Модерна држава треба да посвети толику пажњу, бригу и трошак систематски изграђиваној лажи да све то превазилази њену моћ. Довољно је помислити само да, рецимо у педагогији, све наставне предмете треба изменити у интересу овог циља. Али ништа није важније до фалсификовати историју. О томе се брину целе научне институције. Дете треба тако васпитавати да уопште и не дође до фактичких података и да нема искуства о стварности, чак да веродостојну информацију сматра злонамерном непријатељском пропагандом, а стварност застарелом и превазиђеном фикцијом. Модерна држава не живи од експлоатације рада народа нити од подмуклог терора, него у првом реду од дезинформисаног јавног мњења. ${ }^{24}$

Да би се човјек ослободио сваке моралне одговорности нужно је континуирано и марљиво радити на подривању чињеничних истина. Хенри, коме је лаж постала систематична животна пракса, чак углађена и виртуозна техника, у једном моменту пропагира овакав став када доводи у питање причу о ропству Јевреја у Египту називајући је поетском конструкцијом, производом маште. На том трагу је и Христово постојање једна застарјела и превазиђена фикција. Стив Тешић је упозоравао на овакву погубну праксу сматрајући да се као посљедица погрешне поставке егзистенције настала деформација нужно претворила у свеопшту дезинформацију. У писму за „Њујорк тајмс“ наглашава сљедеће:

Хана Арент, експерт за тоталитарне режиме и тоталитарне начине размишљања, одавно нас је упозорила да може доћи доба када не само да ће се филозофске истине сматрати небитним, већ и чињеничне истине: имена и датуми, ко је шта и коме урадио, ко је био жртва а ко агресор више неће бити важно као чињеница и замијениће се мишљењима.

Чини се да смо доспјели у такво време и баш тако поступили и то не у некој тоталитарној држави већ у слободној држави са слободним медијима. Догађаји у свијету се више не просуђују на темељу снажних доказа или непристрасно. Чак и нормални новинарски стандарди покушавања, настојања да се дође до цјеловите приче, бивају одбачени као исувише тешки и досадни и превише захтјевни. Оно што је замијенило традицију трагања за истином, и филозофском и чињеничном, јесте нека врста претјераног поједностављивања, као из ТВ сапуница, на добре и лоше момке, достојне и недостојне жртве. Бавити се стварима на овај начин доводи до тога да се прави догађаји не рачунају ни за шта

23 Хамваш 2009, 86.

24 Hamvaš 1994, 22. 
и да немају никакву суштинску важност у одлучивању ко је у праву а ко није у одређеном конфликту. ${ }^{25}$

Тешићева проницљива запажања о укидању границе између истине и лажи темељно разрађује Крис Хеџис (Chris Hedges) у студији Царство опсјена (Етріге of Illusion), у којој даје анамнезу савремене Америке тврдећи да је смисао капитализма у способности лагања и манипулисања другима:

Било је још историјских раздобља с високим стопама неписмености и великим пропагандним кампањама. Но, сигурно још од времена фашистичке и совјетске диктатуре, те вјероватно сурове ауторитарне контроле што ју је Католичка црква завела у средњем вијеку, није се тако вјешто и безочно манипулисало самим садржајем информација. Пропаганда је постала замјена за идеје и идеологију. Знање се често брка са осјећајима која су у нама подстакнута. Комерцијални брендови бркају се с изражавањем индивидуалности. А у том вртоглавом урушавању вредносног система и писмености, на тако плодном тлу оних који не могу читати и оних који су престали читати, почиње сјетва из које ће никнути нови тоталитаризам. ${ }^{26}$

Нови тоталитаризам о којем говори Хеџис јесте корпоративна држава чију тиранију аутор препознаје на сваком кораку, закључујући како у таквој форми уређења безбједносне службе цвјетају и доносе се закони типа „Патриота“ који људску слободу претвара у пуку фарсу. Усљед глорификовања похлепе и насиља и чињенице да је Америка највећи извозник оружја, не треба да чуди то што је стопа неписмености запањујућа, и што је морални нихилизам инфицирао и високошколске установе. Чак је и образовање које подстиче студенте на креативност и врлину жртвовано у фаустовском пакту. Хенрија:

Најбољу илустрацију претходно наведеног представља дијалог између Скипа и

ХЕНРИ: Интересује ли те историја? Или филозофија? Гдје си ишао у школу?

СКИП: Студирао сам на Принстону. Али је моје поље интересовања био бизнис, право да ти кажем. Ни филозофија, ни култура, углавном тржиште.

ХЕНРИ: Аха, али поезија и тржиште имају доста тога заједничког, знаш.

СКИП: Поезија и тржиште!

ХЕНРИ: Да, да. И поезија и тржиште су засновани на правилима која кажу да се успјешни никада не покоравају. ${ }^{27}$

Тржиште одређује све вриједности, филозофија опстајања (монетарна економија) потисла је хероизам и племенитост (поезија, умјетност), чак је и поезија претворена у привезак шоу-бизнису. Ову лекцију из монетарне економије, претходно детаљно очишћену од етичких конотација, усвојили су и Хенри и Скип, а особито Феликс. Та лекција поучава да се у животу ради о опстанку. Оно што се рачуна је долазак до врха и останак на врху. Инстинкт опстанка искључив је према религиозном и етичком захтјеву

25 Види: Steve Tesich, “Consider the following”, доступно преко: www.srpska-mreza.com. Превео са енглеског аутор рада.

26 Hedges 2009, 53. Превео са енглеског аутор рада.

27 Miller 2009, 171-172. Превео са енглеског аутор рада. 
„воли ближњег свог.“ Примордијално хумано држање јесте љубав, док се данашње свеколико човјечанство изграђује на мисли о борби за опстанак. Отуда и не чуди то што грађански рат у фиктивној земљи из Милерове драме траје готово четрдесет година и што се радња Тешићеве драме На отвореном друму дешава у вријеме грађанског рата. Укинута је разлика и између рата и мира. Народ се налази између два пуча - један се догодио и пропао, други се припрема. Њихов живот је егзистирање у перманентном преврату, у стању перманентне опсаде.

Мартин Бубер тврди да интензитет човјековог живота има три ступња:

Први је кад неко живи у кругу непосредног објављења. Тако су живели Буда и Мухамед и Бал Шем Тов. То је мит. Легенда је слабија. Човек не живи у свету објављења, него у успомени на њега. Трећи ступањ је сумња, заборав, критика, порицање. $^{28}$

Интензитет живота Милерових ликова одговара трећем ступњу: сумњи, забораву, критици, порицању. Феликс најприје сумња у Ралфово божанско поријекло и сматра да му је задужење, као и Великом инквизитору, да се умијеша тамо гдје се појави свјетлост (истина) и да је угаси. Отуда Феликса можемо посматрати као производ тоталитарног апарата који је реализовао такав систем који је кроз историју унапријед спречавао појаву свјетлости и чак проналазио формуле за прослављање мрака и ропства. Филозоф-купохолик Хенри пориче Христово постојање, сматрајући га поетским конструктом, фикцијом.

У страху од истине, Милерови ликови одбацују, критикују, поричу и желе заборавити Христа, остајући притом у стању ропства које је увијек негирање истине. Тај дух негације уједно је, а на неки начин и неизбјежно, и дух преваре. Блуз за Месију драматизује могућност да човјек постмодерног доба није спреман за спасење. Првобитно желећи да га разапну и од његове смрти профитирају, сви ликови драме на крају моле Ралфа да оде и да се не враћа; они стоје пред трансцендентним али су неспособни за трансцендирање. Христов Други долазак непожељан је и немогућ у свијету у којем је човјекова личност, која је етичка и духовна категорија, претворена у ствар, објект, безличну стихију. Такво преобраћање, сматра руски филозоф Берђајев, значи смрт. У сукобљавању моћи и надличних, виших вриједности, тврди Берђајев, „више вредности у свету показују се слабијим од нижих, више вредности се упињу, ниже тријумфују. Полицајац, наредник, банкар и шпекулант, јачи су од песника и философа. У свету објеката материја је јача од Бога. Син Божији је био разапет. Сократ је био отрован. Пророци су били каменовани.“29 Ралф - револуционар и творац нове мисли и новог живота утемељеног на слободи, љубави и жртви бива угњетаван, умало разапет и на крају прогнан. Тријумфовали су господари и робови - Феликс, Хенри, Скип, Емили и други. Трансцендентно и нада у искупљење не само да су одсутни из таквог свијета већ бивају негирани и одбачени. Ови људи се свјесно одричу слободе личности, неспремни су за самоостварење својих личности које претпоставља сукобљавање и непристајање на конформизам са свијетом, борбу против поробљавајућег друштвеног уређења базираног на теорији која не нуди ништа сем ега. Као што каже Берђајев,

пристајање на ропство умањује бол, и човек лако на то пристаје. Пристајање на ропство умањује бол, непристајање увећава бол. Бол у људском свету је рађање

28 Hamvaš 1994, 200.

29 Berđajev 1991, 75. 
личности, њена борба за свој лик. Већ индивидуалност у живом свету боли. Слобода рађа страдање. Може се умањити страдање, одрицањем слободе. Достојанство човека, то јест личности, то јест слободе претпоставља пристајање на бол, способност да се преживи бол. ${ }^{30}$

Одбацивањем и прогањањем Христа Милерови ликови лишавају себе слободе савјести и просуђивања, разликовања добра и зла, истине и лажи, стварности и привида. Радикална промјена, некада схватана као морални императив, сада бива претворена у пуку химеру. Неравноправност и патња не бивају разријешени ангажованом савјешћу већ погоршани анархичним насиљем и самољубљем. С једне стране се налази побуњени човјек (Ралф) изнурен апсурдношћу система у којем је приморан да учествује. С друге стране су они (Феликс, Хенри, Скип, Емили) паралисани сумњом у себе, загњурени у сопствени еготизам, отуђујући се од стварности тренутним задовољствима или сновима сатканим од похлепе. Стварно, у међувремену, бива прерађено у форму забаве, живот претворен у животни стил, бол максимално ублажен, патња приказана као производ који је комерцијализован и претворен у масовно тржиште.

Устукнувши пред неуспјелом утопијом, одбијајући стратегију друштвеног ангажовања, Милерови смушени ликови траже склониште у разоноди, која је расијаност и небрига, испаравање у празнини. Сол Белоу овакву расијаност и разоноду назива „моронским инферном“, што је врло упечатљив опис свијета који је изгубио ослонац и везу са стварношћу. Када је Милер написао свој комад, капитализам је био на врхунцу своје моћи, а капитализам је несумњиво крајњи облик прагматизма. Вриједности не потичу од Бога или просвијећене радничке класе већ их диктира безлично тржиште, нови вид Дарвинизма, природна селекција током које се идеје, вриједности и принципи оцјењују спрам њихове употребне вриједности. Ако Америка није службено забранила хришћанство и античку филозофију као што је то учинила са комунизмом, учинила је нешто цјелисходније: кроз уста Вилијама Џејмса објавила је да корисност твори критеријум истинитог и да се вриједност сваке концепције, чак метафизичке, мјери њеном практичном дјелотворношћу, што у оквиру америчког менталитета на крају готово увијек треба да значи друштвено-економском дјелотворношћу. Сљедствено томе и Христово учење бива мјерено критеријумима новчане економије и самим тим процијењено као небитно, а врлине које захтијева сваки натприродни циљ на крају бивају проглашене за бескорисне и чак шкодљиве.

Мистериозна фигура у Блузу за Месију Ралф, исијава бљештаву свјетлост у коју нико не жели да се загледа. Он је оваплоћење савјести (и љубави) као органа смисла, која је по Виктору Франлу глас трансценденције. Као такав он се мора негирати и одбацити у име материјализма и личног интереса јер је савјест оно пред чим је човјек одговоран и зато што савјест стоји у оштрој противности са свим циљевима који се човјеку пружају у име материјализма. Хенријева одлука да је боље усмртити Христа него му дозволити да наруши њихово царство оспјена и славе без одговорности има паралелу у бојазни Стива Тешића да постмодерни човјек тежи да се отараси чак и памћења да је такав човјек икада постојао, као и у Хајдегеровој идеји да човјек починио издају сакралне узвишености свог живота и да данас у бивству заборава више и не живи. Као и Шекспиров Ричард Трећи, и Хенри је ,ријешен да завриједи као хуља““ кад већ није кадар да што завриједи као љубавник. Економски и социјални интереси заузимају мјесто у првом плану, и могу се задовољити искључиво на уштрб моралног квалитета.

30 Ibid., 44. 
Надахнуте говоре Милерових ликова прожима култ антиживота, кварења живота, демонска фикс-идеја, плаховитост и стрка (Феликс, Хенри, Скип, Емили). Неспособан за однос ја - ти, демон нема своје ти; боји се свјетлости (Ралф/Христ). Мада се духовни вођа Ралф никада физички не појављује на сцени, попут Бекетовог Годоа, он зрачи необјашњивом свјетлошћу која је свепрожимајућа. Феликс не успијева рационално објаснити Ралфово „емитовање“ овакве свјетлости као ни његову способност да се избави из затвора ходањем кроз зидове, и тврдоглаво одбија да у свему томе види еманацију духовности.

ФЕЛИКС: У реду, Не схватам то! Да ли ти разумијеш компјутерски чип? Можеш ли ми објаснити струју? А ген? [...] Па шта ако он свијетли; то је једна ствар више, то је све. Али погледај га само, да ли си икада видео такву тоталну празнину на лицу једног човјека? $[\ldots]^{31}$

Очи у систему тамнице, у систему бордела, очи застрте велом, очи сломљене у лажи живота једва и да виде нешто друго до новац. Човјек (Феликс) не види ни најочигледније чињенице, јер његова лажна егзистенција apriori затамни његово виђење. Лажна егзистенција мора и може да види само фалсификован свијет. Шта год да се појави из планинских села, чак и спаситељ, за Феликса је тек доказ шокантног пуког провинцијализма. Његова редовна путовања у Мајами, гдје иде код свог психоаналитичара, зубара, посјећује своје проститутке и своје америчке војне савјетнике, помажу му да остане у стању постојане индиферентности према свему ономе што се дешава у земљи којом управља. Када Хенри ламентира над чињеницом да је земља за коју су се некада обојица борили сада у стању распада, Феликс га прекида ријечима: „Слушај, након тридесетосмогодишњег грађанског рата шта си очекивао да ћеш наћи овдје, Шведску?“32 Након смрти своја два брата који су настрадали у борбама, Феликс је научио да игнорише мртве бебе на улицама, наркотизован терапијом такозване позитивне психологије. Сврха такве психологије јесте у парализовању критике и претварању људи у ходајуће будале којима на челу пише: само се забављај, то јест хљеба и игара. Као хиперконзумента индустрије забаве, Феликса интересују само најновији шопинг центри у граду и проститутке. Бела Хамваш каже да човјек, ако се забавља, расије себе и расијан је. Посљедица: не обраћа пажњу. Чак не може ни да се наспава. Стварност га се не дотиче, једино му је занимљива.

По природи утилитариста и себичњак, Феликсу Ралфове натприродне способности дјелују примамљиво јер у њима види потенцијални лијек за сопствену импотенцију. Темељна идеологија овдје је користољубље, еголатрија, бављење самим собом, које искључује љубав према другом, искључује дијете, жену, религију, умјетност и метафизику. Као што каже Хенри: „човјек мора научити да живи у врту својег ја.“33 Феликсов псеудоегзистенцију понајбоље дефинише термин луциидност чија је главна снага инстинкт власти: „Луцидност има само животну категорију, нема категорију духа, због тога није универзално хумана, због тога у њој нема женског ни дечјег, нити зреле страсти, и нема имагинације, маште, сна, уметности, нема у њој морала, и нарочито нема љубави. “"34

31 Miller 2009, 144. Превео са енглеског аутор рада.

32 Ibid., 137. Превео са енглеског аутор рада.

33 Ibid., 184. Превео са енглеског аутор рада.

34 Hamvaš 1994, 53. 
Осим борбе између резигнираности и ангажовања, стварности и њеног привида, Блуз за Месију драматизује и сукоб између разума и романтизма, од којих ниједан не даје одговор на људске истинске потребе. Разум није окончао сиромаштво нити омогућио да правда завлада. Хенри окреће леђа разуму и покушава се опробати у романтизму и мистицизму, и на крају доспијева до цинизма. Доба вјере (The Age of Faith), Доба Разума (The Age of Reason) и Доба револуције (The Age of Revolution) извргли су се у еру којом суверено влада идеологија личног интереса.

Блуз за Месију није само текст о Америци или некој далекој земљи што се полагано али сигурно стропоштава из једне форме репресије у другу, односно из стања грађанског рата прелази у фазу милитаристичке диктатуре и криминала, гдје је све дозвољено, чак и антропофагија. Као и сваки блуз, овај комад је ламент над патњом; он је текст о болу, који је захватио како лични тако и јавни живот, драма о губитку смисла и вапајем за смислом, свједочанство о Америци као пуком агрегату појединаца, сметлишту гдје се окупља оно што је другдје одбачено, посвијећено потрошњи - једном ријечју, о мјесту гдје нема културе. Упркос хуморичности, драма казује о загушењу, кварењу и коначном краху људских веза, повременим издајама, језику бесмисла, похлепи прерушеној у принцип.

Питање које Милерова драма поставља јесте с којом трансцедентном/надличном идејом човјек дочекује сваки нови дан, односно је ли сама идеја трансцедентног/надличног остала саставни дио историје и традиције у које човјек више не вјерује. Ралф на крају драме одлази односно бива отјеран а с њим нестаје и спасоносна свјетлост, то јест нада и вјера. Прошлост и традиција се немилосрдно, систематски уништавају, чинећи спас немогућим оног тренутка када се „поједници сведу на пуки низ тренутних искустава која не остављају трага, или прије чији траг је омражен као ирационалан, површан и 'превладан' у правом смислу ријечи.“" ${ }^{35}$ Сведени на такав начин, појединци засигурно неће тражити безбједност у нади - то јест у идеји која тек треба да буде консолидована у реалности. Као што је Пјер Бурдије запазио, људи који не посједују ни дјелић контроле над својом садашњицом - а већина ликова из Милерове драме, као што смо видјели, изгледа има тек магловиту слику о томе шта носи садашњост, нијесу у стању да смогну храброст која је потребна да би се будућност контролисала.

Блуз за Месију је такође и јетка сатира, најпотпунија и најпрецизнија пародија друштва испражњеног од вриједности и непособног да разлучи стварност од опсјене. Ријеч је о свијету који се више не надахњује вјером у Бога, у којем је чак и логика неважећа, неважећи је чак и морал, чак су неважећи и закони органског живота, опстајава само материјализам. „Свијет жели да буде преварен“, каже Адорно, кога цитира Бауман наводећи да његова директна пресуда подсјећа на коментар „Фојтвангерове тужне приче о Одисеју и свињама или, с тим у вези, приче Ериха Фрома о 'бјекству од слободе', али као архетип свих тих прича, Платонова меланхолична спекулисања о трагичној судбини филозофа који настоје да подијеле с онима у пећини добре вијести донијете из сунцем обасјаног свијета. “36

Милерова драма се може посматрати као политички комад, као дебата о неправди и неопходности моралног бунта и друштвено ангажованог дјеловања. Премда се ради о комаду који у своје средиште поставља озбиљна морална питања, она је у исти мах и сатира и комедија у стилу Џонатана Свифта, и продорна кубистичка слика хорора савремене цивилизације која је своје вриједности жртвовала у фаустовској погодби; застрашујући пикасовски портрет свијета гдје се на сваком кораку препознаје тиранија

35 Adorno, Horkheimer 1989, 15.

36 Bauman 2009, 168-169. 
корпоративне државе, доминација слике и симулације гдје ствар није онаква каква постоји, него како дјелује, и гдје се човјек не процјењује према његовом стварном животу, него према његовом глумачком учинку; гдје медијска фатаморгана диригована из невидљивих и утолико опаснијих центара моћи на перфидан начин настоји претворити човјека у субнормалног како би њиме владала. Од слободе за којом је човјек толико чезнуо, преостала је само слобода незаинтересованости и апсолутне баналности.

\section{Литература}

Берђајев, Николај (1998): Дух и слобода: проблематика и апологија Хришћанства. Београд: Логос ант.

Хамваш, Бела (2009): Пут предака и пут богова. Превод и поговор Сава Бабић. Београд: Тардис.

Шпенглер, Освалд (2010): Пропаст Запада I-II. Београд: Утопија.

Adorno, Theodor \& Horkheimer, Max (1989): Dijalektika prosvjetiteljstva: filozofijski fragmenti. Sarajevo: Veselin Masleša-Svjetlost.

Baudrillard, Jean (1994): Simulacra and Simulation. Trans. Sheila Faria Glaser. Ann Arbor: The University of Michigan Press.

Baudrillard, Jean (1988): America. London: Verso.

Bauman, Zigmunt (2009): Fluidni život. Novi Sad: Mediterran Publishing.

Bauman, Zigmunt \& Donskis, Leonidas (2018): Fluidno zlo. Novi Sad: Mediterran Publishing.

Bigsby, C. W. E. (2008): Arthur Miller: The Definitive Biography. Weidenfeld \& Nicolson.

Berđajev, Nikolaj (1991): O čovekovom ropstvu i slobodi. Novi Sad: KZNS.

Lehan, Richard (1998): The City in Literature: an Intellectual and Cultural History. Berkeley/Los Angeles/London: University of California Press.

Miller, Arthur (2009): Complete Plays I-VI. London: Methuen drama.

Miller, Arthur (1988): Timebends: A Life. London: Methuen.

Miller, Arthur (1992): “Get It Right. Privatize Executions.” Мау 8, доступно преко: http://www.nytimes.com/books/00/11/12/specials/miller-executions.html

Tesich, Steve \& Nadja, Essays. Доступно преко: http://www.srpska mreza.com/ authors/Tesich/nadja-intro.htm

Hamvaš, Bela (1994): Patam. Beograd: Centar za geopoetiku.

Hedges, Chris (2009): Empire of Illusion: the End of Literacy and the Triumph of Spectacle. New York: Nation books. 


\section{Radoje V. Šoškić}

\section{THE MOTIF OF CHRIST'S SECOND COMING IN ARTHUR MILLER'S RESURRECTION BLUES}

The paper strives to analyze the motif of Christ's Second Coming in Arthur Miller's play Resurrection Blues (2002), which thematizes the twilight of the American culture and society as a form of moral, intellectual and spiritual nihilism caused by the insidious ideology of capitalism and corporate power. The characters in Miller's play epitomize intellectual, political, and psychological troubles of contemporary American society. Furthermore, they symbolize the ultimate form of spiritual and moral torpor caused primarily by their escape from freedom understood as the will to meaning that God has endowed them with, then their loss of contact with other human beings and the natural order of things. In dramatizing the killing of Christ, Miller shows that evil arises from modern man's desire to escape from his/her conscience. In the play, Christ is understood as the archetype of the wholeness of human being, whose crippling or neglecting inevitably frustrates the development of the human personality, which is man's task and ideal. The paper also interprets the play in the light of its critique of the American entertainment industry, consumer culture, and celebrity culture where human beings become a commodity, objects, like consumer products. The ideas of Nikolai Berdyaev, Bela Hamvas, Jean Baudrillard, and Zigmunt Bauman provide the theoretical framework for our analysis. 